\title{
MODEL KOMUNIKASI KELOMPOK TENTANG MAKNA PERNIKAHAN ANTARGENERASI DI KALANGAN KELAS MENENGAH JAKARTA
}

\author{
Nur Kholisoh dan Primayanti \\ Program Magister Ilmu Komunikasi Pascasarjana Universitas Mercu Buana, Jl. Menteng \\ Raya No.29 Jakarta Pusat 10340, No Telp +628568804868. \\ Email: kholisoh.nur@gmail.com
}

\begin{abstract}
Nowadays the meaning of marriage has changed as found in various phenomena of exiting from state regulations and laws, religion, customs and norms in society. The research aims at finding interaction model and group communication leading to changes of meaning of marriage among inter-generation of middle-class groups in in DKI Jakarta. This research refers to Alfred Schutz teories of symbolic interactionism, group-communication, and social phenomenology. Qualitative research method is used to analyze data completed by depth interview and FGD as data collection technique. The results shows that interaction model on mariage meaning is influenced by the way people grow, interact, and communicate within their group. The meaning of marriage symbols which is exchanged in the interaction of a group has changed from one generation to the next generation. Marriage is perceived as destiny, the unity between man and woman as a way of preserving human beings, justifying sexual intercourse and holding religious order. The research also fond contradictive phenomenon of marriage meaning between marriage meaning with the sacred law of marriage, whether it is in state regulations, customs and norms of society, such as same-sex marriage phenomenon (gay/lesbian), swinging behavior, samen leven, and free sex.
\end{abstract}

Keywords: marriage meaning, group communication and symbolic interactionism

\begin{abstract}
Abstrak
Saat ini makna pernikahan mengalami perubahan dengan berbagai fenomena yang keluar dari aturan negara, agama, adat istiadat dan norma masyarakat. Penelitian ini bertujuan untuk menemukan model interaksi dan komunikasi kelompok yang menghasilkan perubahan makna pernikahan antar generasi di kalangan kelas menengah di DKI Jakarta. Teori interaksionisme simbolik dan teori komunikasi kelompok serta fenomenologi sosial Alfred Schutz menjadi rujukan penelitian ini. Metode penelitian kualitatif digunakan untuk menganalisis data dilengkapi dengan depth interview dan FGD sebagai teknik pengumpul data. Hasil penelitian berupa model interaksi mengenai pandangan terhadap makna pernikahan sangat dipengaruhi oleh cara seseorang dibesarkan, berinteraksi dan berkomunikasi di dalam kelompoknya. Makna dari simbol-simbol pernikahan yang dipertukarkan dalam interkasi suatu kelompok telah mengalami perubahan dari satu generasi ke generasi berikutnya. Pernikahan dimaknai sebagai kodrat, penyatuan antara laki-laki dan perempuan sebagai satu cara untuk melestarikan umat manusia, menghalalkan hubungan seksual dan menjalankan perintah agama. Hasil penelitian juga menemukan adanya fenomena yang bertentangan antara makna pernikahan dengan kesakralan hukum pernikahan, baik secara aturan negara, adat serta norma masyarakat, seperti fenomena pernikahan sejenis (gay/lesbian), perilaku tukar menukar pasangan, kumpul kebo dan seks bebas.
\end{abstract}

Kata kunci: makna pernikahan, model komunikasi kelompok, interaksionisme simbolik

\section{Pendahuluan}

Pernikahan merupakan bentuk pengikatan janji nikah yang dilakukan oleh dua orang untuk meresmikan ikatan perkawinan secara norma agama, hukum, maupun sosial. Dalam ikatan pernikahan terdapat pola-pola interaksi dan komunikasi antar individu, baik pada individu yang menikah maupun individuindividu yang berada di sekitarnya. Polapola interaksi ini membuat masing-masing individu dalam sebuah kelompok memiliki 
pemahaman, pengetahuan maupun pengalaman sebagai dasar pengambilan keputusan. Sudut pandang individu yang menjalani pernikahan, maupun individu yang ada di sekitar pasangan yang menikah, menjadi penting untuk dipahami sebagai sebuah realitas sosial dan menjadi sumber dari gambaran dan pemahaman perubahan makna pernikahan dari generasi ke generasi. Pasangan yang menikah dan keluarga besarnya, maupun lingkungan pasangan tersebut, menjadi bagian dari interaksi komunikasi yang memuat pesanpesan untuk dimaknai.

Komunikasi kelompok sebagai sarana penyampaian pesan, apapun substansi dan format pesannya, termasuk konten pesan yang mengandung nilai kehidupan dan norma pernikahan, memegang peran penting dalam proses transformasi pesan. Pada umumnya kelompok mengembangkan norma atau peraturan mengenai perilaku yang diinginkan untuk kelompok tersebut. Norma atau peraturan yang berlaku pada anggota perorangan dan atau kelompok tersebut akan berbeda antar satu kelompok dengan kelompok lain.

Hal ini memungkinkan terjadinya perbedaan dalam mengaplikasikan satu norma atau nilai antar satu kelompok dengan kelompok yang lain dan bahkan memungkinkan terjadi pergeseran atau perubahan dalam mengakomodasi dan menjalani suatu pesan atau kecenderungan perilaku secara mendasar. Terpaan pesan yang diterima secara berbeda antar anggota kelompok dan antar kelompok memungkinkan terjadi pergeseran makna pada hal-hal substansi yang selalu terjadi dari waktu ke waktu, seperti pembentukan makna pernikahan. Perbedaan itu dimungkinkan terjadi akibat banyak faktor seperti kurun waktu yang panjang, berubahnya arti sakral dalam pernikahan, melonggarnya ketentuan aturan adat, pandangan individu atau kelompok yang berbeda terhadap ajaran agama, terjadi pergeseran nilai dalam pandangan kesamaan jenis kelamin antara suami dan isteri, pandangan terhadap cara alami pelestarian keturunan, perubahan kecenderungan perilaku seksual atau faktor yang mempengaruhi tujuan menikah juga sangat mungkin terjadi pada anggota satu kelompok maupun antar kelompok.

Pernikahan, secara umum adalah ikatan antara sepasang manusia, lakilaki dan perempuan, dalam menetapkan hak dan kewajiban, anak dan keberadaan mereka di bawah hukum yang diakui, baik hukum agama, konstitusi negara, adat maupun norma masyarakat. Secara prinsip pernikahan merupakan pengakuan hubungan interpersonal atas keintiman dan seksualitas. Pada semua agama dan banyak budaya, pernikahan wajib dilakukan sebelum melakukan aktivitas seksual.

Saat ini terjadi perubahan realitas pernikahan dengan berbagai fenomena yang keluar dari aturan negara, agama, adat dan norma masyarakat. Pesatnya perkembangan teknologi komunikasi dengan berbagai pesan yang disiarkan, menghilangkan batas-batas privasi individu yang pada akhirnya memunculkan pandangan baru tentang pernikahan. 
Fenomena perubahan makna perkawinan dari generasi ke generasi menjadi satu hal yang menggelitik untuk diteliti, terutama dari sisi komunikasi mengingat penelitian komunikasi pada dasarnya adalah mempelajari pola-pola interaksi antar individu dalam suatu kelompok sosial, dengan titik berat tertentu yaitu pengambilan keputusan, suatu situasi di mana seseorang harus menentukan pilihan di antara kemungkinankemungkinan yang ada dan dengan segala konsekuensi yang menyertainya. Rentang generasi sepanjang 20 tahun memuat interaksi komunikasi yang sedemikian massif yang memungkinkan mencuatnya banyak pengetahuan dan pemikiran baru terhadap hal-hal substansi termasuk konsep pernikahan. Peralihan generasi dengan karakternya masing-masing mengakibatkan munculnya pemahaman, pengetahuan dan kesadaran yang berbeda pada banyak hal. Generasi Baby Boomers dengan karakter pasca Perang Dunia II tentu berbeda dengan karakter Generasi X dan Generasi Y sebagai generasi pelanjut Baby Boomers.

Pilihan terhadap pasangan hidup juga mengalami perubahan dari generasi ke generasi. Jika pada generasi Baby Boomers penentuan pasangan hidup seorang anak menjadi hak prerogatif orang tua, maka pada Generasi $X$ pemilihan pasangan hidup merupakan hak privacy seorang anak yang tidak boleh diambil alih oleh siapapun termasuk orang tuanya. Hasil penelitian Lubis dan Khasiah yang dimuat dalam Jurnal Komunikasi ASPIKOM Vo. 2 Nomor 6, Januari 2016 menyatakan bahwa
“... biasanya anak tidak bisa menghindar dari jodoh yang telah dicarikan mamak dan disetujui oleh orang tuanya, sehingga anak hanya bisa pasrah dengan pilihan tersebut. Akan tetapi adat mencarikan jodoh sudah mulai hilang. Sekarang anak itu sendiri yang mencari dan menemukan jodohnya." Komunikasi seperti apa yang terjadi dari generasi ke generasi dalam memaknai pernikahan sehingga terjadi perubahan makna perkawinan itu sendiri, menjadi fokus dan titik sentral dalam penelitian ini.

Kelompok individu yang memiliki keleluasaan untuk diakses di wilayah DKI Jakarta dan sekitarnya adalah kelas menengah karena jumlahnya kian banyak dan kian menunjukkan eksistensinya, baik sebagai entitas sosial maupun bisnis, terutama di kota-kota besar. Di wilayah DKI Jakarta dan sekitarnya, jumlah masyarakat Indonesia yang termasuk dalam kelompok kelas menengah mengalami peningkatan pesat.

Menurut Yuswohady yang juga pemimpin perusahaan konsultan Center for Middle Class Consumer, terdapat delapan wajah karakter segmen kelas menengah Indonesia, yaitu The Aspirator. Wajah kelas menengah ini versi The Aspirator mewakili karakter idealis, memiliki tujuan, serta menjadi influencer terhadap komunitasnya. Karakter kedua, The Perfomer. Kalangan ini diwakili kalangan profesional serta entrepreneur yang terus berusaha mengejar karier (self-achievement). Karakter ketiga, The Expert. Tipe ini diwakili orang yang selalu berupaya menjadi ahli di bidangnya. Memiliki sifat kekeluargaan yang tinggi, 
serta menjunjung tinggi norma-norma sosial dan kekeluargaan (traditional values).

Sedangkan yang keempat, The Climber. Karakter tipe ini sangat economic-oriented. Risk taker dalam karier, serta menilai penghargaan dalam karier itu merupakan hal penting. Karakter kelima adalah Trend Setter. Konsumen kelas menengah ini berkarakter sedikit jarang bersosialisasi, jarang memutakhirkan informasi, tetapi kemampuan finansialnya lumayan tinggi.

Karakter keenam, The Follower. Tipe ini perilakunya sangat digerakkan oleh kondisi lingkungan sekitarnya. Ekspresi diri diejawantahkan dalam barang-barang bersifat life-style. Karakter ketujuh, The Settler. Kelompok ini mapan secara ekonomi dan finansial, karena umumnya kelompok ini berasal dari kelompok pedagang yang sukses. Karakter terakhir, kedelapan, The Flower. Tipe ini bisa dikenali dengan kurangnya mengikuti perkembangan teknologi. Menjalani kehidupan mengalir seperti apa adanya. Menjunjung tinggi nilai-nilai spiritual serta menjadikan keluarga menjadi dunianya. Pegawai Negeri Sipil (PNS) dan Ibu Rumah Tangga mendominasi kelompok menengah tipe ini.

Dari delapan karakteristik kelas menengah itu dapat ditarik kesimpulan bahwakelompokkelas menengahIndonesia, termasuk yang menetap di wilayah perkotaan seperti di provinsi DKI Jakarta, adalah mereka yang pakar atau profesional, melek teknologi, menjunjung nilai-nilai spiritual, memegang norma keluarga, mengakses informasi dan internet \& melek gaya hidup. Gambaran umum karakter kelas menengah ini adalah kelompok yang menjadikan komunikasi sebagai sisi signifikan dalam pengembangan kualitas kehidupan. Kelompokini jugaberkebutuhan besar pada akses pendidikan sebagai sarana memperkaya ilmu pengetahuan dan melebarkan jejaring pertemanan. Pada kelompok menengah, proses komunikasi berkembang lebih optimal karena mereka haus akan perkembangan teknologi komunikasi dalam berbagai format.

Kelas menengah tumbuh dan berkembang seiring dengan peningkatan pesat perekonomian DKI Jakarta yang melahirkan area-area baru bagi kalangan urban. Dari konsentrasi kalangan urban inilah, kelompok kelas menengah itu beranak pinak dan lestari dari generasi ke generasi. Dengan karakter berpola pikir global, jejaring komunikasi di kalangan menengah menjadi sedemikian luas. Mereka berinteraksi satu sama lain, dari generasi ke generasi, saling tertarik, saling jatuh cinta dan mengikat diri melalui perkawinan. Saat ini di DKI Jakarta, komunikasi mereka sudah berkembang dari level kakek-nenek ke ayah-ibu, kemudian ke level anak-cucu dan cicit. Komunikasi kelompok pada level usia kakek-anak-cucu-cicit inilah yang akan diteliti sehingga ditemukan penyebab perubahan makna pernikahan dari generasi ke generasi pada kelas menengah di DKI Jakarta dan sekitarnya.

Cara-cara manusia membentuk makna terjadi melalui percakapan. Menurut Barbara Ballis (Littlejohn:2014:231), 
manusia memahami pengalaman mereka melalui makna-makna yang ditemukan dalam simbol-simbol dari kelompok utama mereka dan bahasa merupakan bagian penting dalam kehidupan social. Sementara itu, kehidupan sosial terdiri dari proses interaksi dari susunan dalam masyarakat melalui percakapan yang terus berubah.

Interaksi dalam komunikasi kelompok antara lain dijumpai dalam bentuk percakapan. Percakapan merupakan sejumlah proses yang di dalamnya para komunikator mengkoordinasikan atau mengorganisasikan interaksi yang menuju pada penciptaan pola-pola yang koheren akan makna/arti. Percakapan adalah urutan interaksi dengan awal dan akhir yang pasti, saling bergantian bicara dan dengan semacam tujuan atau serangkaian target. Percakapan juga punya aturan main, percakapan memiliki struktur dan tampilan koherensi dan rasa. Percakapan mencakup semua jenis interaksi, termasuk pembicaraan sosial serta debat dan argumen, upaya pemecahan masalah, episode konflik, saling bersikap romantis dan berbagai jenis lain dari wacana di mana komunikator dapat menggunakan bahasa dan komunikasi non-verbal untuk berinteraksi dengan satu sama lain

Percakapan bukan hanya interaksi sehari-hari yang informal, tetapi memiliki makna khusus. Percakapan menurut Littlejohn (2014:215) merupakan sebuah rangkaian interaksi dengan awal dan akhir, pergantian giliran yang jelas, serta beberapa maksud dan tujuan. Percakapan juga diatur oleh aturan-aturan serta mempunyai hubungan tampilan dan struktur serta makna. Percakapan tentang makna dari pernikahan terus berlangsung dari waktu ke waktu dengan menggunakan bahasa, baik secara verbal maupun nonverbal, untuk saling berinteraksi. Interaksi manusia melibatkan bahasa sebagai sarana untuk menyampaikan pesan. Bagaimana pesan tentang pernikahan disusun dan dikomunikasikan dalam kelompok masyarakat, kata-kata dan simbol apa yang ada di dalam pesan tersebut serta bagaimana pesan tersebut diartikan, disampaikan melalui bahasa yang disepakati dan dipahami oleh kelompok masyarakat.

Bahasa yang digunakan dalam komunikasi, baik yang bersifat verbal maupun nonverbal, bukan merupakan hal yang statis tetapi bersifat dinamis. Ferdinand de Saussure (Littlejohn:2014:155) menyatakan bahwa bahasa dapat berubahubah. Bahasa yang berbeda menggunakan kata-kata yang berbeda untuk hal yang sama, seperti halnya dengan kata yang digunakan dalam memaknai pernikahan. Bahasa juga merupakan sebuah sistem dari representasi sosial. Realitas sosial masyarakat mengalami perkembangan dan perubahan dari waktu ke waktu yang dipengaruhi oleh perubahan makna dalam interaksi yang terjadi di dalamnya. Makna pernikahan sebagai salah satu pesan dari sekian banyak pesan yang ada di dalam masyarakat juga mengalami perubahan yang turut menentukan representasi sosial dari satu generasi ke generasi berikutnya.

Komunikasi kelompok adalah suatu kajian tentang interaksi individu dalam 
kelompok kecil atau kurang dari 20 orang, dengan kadar spontanitas, strukturalisasi, kesadaran akan kelompok, ukuran kelompok, relativitas sifat permanen dari kelompok serta identitas diri dalam ukuran tertentu. Kelompok memiliki bentuk yang dapat dilihat dari pola interaksi setiap waktu. Menurut Liittlejohn (2005:215), sesuatu diciptakan melalui interaksi dalam kelompok, termasuk peran dan norma, serta hubungan dan penyelesaian tugas. Struktur kekuatan juga dibentuk dalam pola interaksi ini.

Teori Komunikasi Kelompok sebagaimana disampaikan Michael Burgoon dan Michael Ruffner dalam buku Human Communication, A Revision of Approaching Speech/Communication, memberi batasan komunikasi kelompok sebagai interaksi tatap muka dari tiga atau lebih individu guna memperoleh maksud atau tujuan yang dikehendaki seperti berbagi informasi, pemeliharaan diri atau pemecahan masalah sehingga semua anggota dapat menumbuhkan karakteristik pribadianggota lainnya dengan akurat. Ada empat elemen yang tercakup dalam definisi di atas, yaitu interaksi tatap muka, jumlah partisipan yang terlibat dalam interaksi, maksud atau tujuan yang dikehendaki dan kemampuan anggota untuk dapat menumbuhkan karakteristik pribadi anggota lainnya. Selain itu terdapat dua karakteristik yang melekat pada suatu kelompok, yaitu norma kelompok dan peran anggota kelompok. Norma adalah persetujuan atau perjanjian tentang bagaimana orang-orang dalam suatu kelompok berperilaku satu dengan lainnya. Ada tiga kategori norma kelompok, yaitu, norma sosial, prosedural dan tugas. Norma sosial mengatur hubungan di antara para anggota kelompok. Sedangkan norma prosedural menguraikan dengan lebih rinci bagaimana kelompok harus beroperasi, seperti bagaimana suatu kelompok harus membuat keputusan, apakah melalui suara mayoritas ataukah dilakukan pembicaraan sampai tercapai kesepakatan. Dan norma tugas memusatkan perhatian pada bagaimana suatu pekerjaan harus dilaksanakan. Ada dua fungsi peran dalam suatu kelompok, yaitu fungsi tugas dan fungsi pemeliharaan.

Teori interaksionisme simbolik Herbert Blumer memiliki tiga premis yakni manusia bertindak terhadap sesuatu atas dasar makna yang mereka miliki atas sesuatu tersebut, bahwa makna tersebut berasal dari, atau muncul dari interaksi sosial yang dimiliki seseorang dengan rekan-rekannya yang lain dan makna ini ditangani dan dimodifikasi melalui proses penafsiran yang digunakan oleh orang tersebut dalam berurusan dengan halhal yang ditemui. Teori Interaksionisme Simbolik menekankan bahwa manusia atau individu, hidup dalam suatu lingkungan yang dipenuhi oleh simbol-simbol. Tiap individu yang hidup akan memberikan tanggapan terhadap simbol-simbol yang ada, seperti penilaian individu menanggapi suatu rangsangan (stimulus) dari suatu yang bersifat fisik. Pemahaman individu terhadap simbol-simbol merupakan suatu hasil pembelajaran dalam berinteraksi di tengah masyarakat, dengan cara meng- 
komunikasikan simbol-simbol yang ada di sekitar mereka, baik secara verbal maupun perilaku non verbal. Proses kemampuan berkomunikasi, proses belajar, serta memahami suatu makna di balik simbolsimbol yang ada, menjadi keistimewaan tersendiri bagi manusia dibandingkan mahluk hidup lain. Kemampuan manusia inilah yang menjadi pokok perhatian teori interaksi simbolik dalam penelitian ini.

Sementara itu, menurut Mead (Ritzer: 340) keseluruhan sosial mendahului pemikiran individual, baik secara logika maupun temporer. Individu yang berpikir dan sadar diri adalah mustahil menurut teori Mead, tanpa didahului adanya kelompok sosial. Kelompok sosial muncul lebih dulu, dankelomopok sosial menghasilkan perkembangan keadaan mental kesadaran diri. Tiga tema konsep pemikiran George Herbert Mead yang mendasari interaksi simbolik antara lain, pentingnya makna bagi perilaku manusia, pentingnya konsep mengenai diri dan hubungan antara individu dengan masyarakat. Tema pertama pada interaksionisme simbolik berfokus pada pentingnya membentuk makna bagi perilaku manusia, dimana dalam teori interaksionisme simbolik tidak bisa dilepaskan dari proses komunikasi, karena awalnya makna itu tidak ada artinya, sampai pada akhirnya di konstruksi secara interpretif oleh individu melalui proses interaksi, untuk menciptakan makna yang dapat disepakati secara bersama

Ciri khas teori interaksi simbolik terletak pada penekanan manusia dalam proses saling menerjemahkan, dan saling mendefinisikan tindakan, tidak dibuat secara langsung antara stimulus-respons, tetapi didasari pada pemahaman makna yang diberikan terhadap tindakan orang lain melalui penggunaan simbol-simbol, interpretasi, dan pada akhirnya tiap individu tersebut akan berusaha saling memahami maksud dan tindakan masingmasing, untuk mencapai kesepakatan bersama. Menurut George Herbert Mead, interaksi simbolik ada karena ide-ide dasar dalam membentuk makna yang berasal dari pikiran manusia (Mind), mengenai diri (Self), dan hubungannya di tengah interaksi sosial, dan bertujuan akhir memediasi, serta menginterpretasi makna di tengah masyarakat (Society) dimana individu tersebut menetap. Pikiran (Mind) adalah kemampuan untuk menggunakan simbol yang mempunyai makna sosial yang sama, dimana tiap individu harus mengembangkan pikiran mereka melalui interaksi dengan individu lain.

Sedangkan diri (Self) adalah kemampuan untuk merefleksikan diri tiap individu dari penilaian sudut pandang atau pendapat orang lain. Diri bukanlah suatu obyek melainkan adalah proses sadar yang mempunyai kemampuan untuk memberikan jawaban atau tanggapan kepada diri sendiri sebagaimana orang lain juga memberikan jawaban atau tanggapan. Sementara masyarakat (Society) adalah jejaring hubungan sosial yang diciptakan, dibangun, dan dikonstruksikan oleh tiap individu di tengah masyarakat, dan tiap individu tersebut terlibat dalam perilaku yang mereka pilih secara aktif dan sukarela, yang pada akhirnya mengantarkan manusia dalam proses pengambilan peran di tengah 
masyarakatnya.Tigatemakonsep pemikiran George Herbert Mead yang mendasari interaksi simbolik antara lain, pentingnya makna bagi perilaku manusia, pentingnya konsep mengenai diri dan hubungan antara individu dengan masyarakat. Tema pertama pada interaksionisme simbolik berfokus pada pentingnya membentuk makna bagi perilaku manusia, dimana dalam teori interaksionisme simbolik tidak bisa dilepaskan dari proses komunikasi, karena awalnya makna itu tidak ada artinya, sampai pada akhirnya di konstruksi secara interpretif oleh individu melalui proses interaksi, untuk menciptakan makna yang dapat disepakati secara bersama.

Menurut Schutz, manusia mengkonstruksi makna di luar arus utama pengalaman melalui proses pentipe-an atau tipikasi. Makna adalah kerjasama antara obyek nyata dan obyek dalam persepsi yang terletak pada hubungan antara obyek nyata dalam persepsi. Hubungan antar makna pun diorganisasikan melalui proses tipikasi tersebut atau biasa juga dinyatakan sebagai stock of knowledge yang menjelaskan bahwa kumpulan pengetahuan memiliki kegunaan praktis dari dunia itu sendiri, bukan sekedar pengetahuan tentang dunia. Inti pemikiran Schutz adalah bagaimana memahami tindakan sosial melalui penafsiran. Proses penafsiran dapat digunakan untuk memperjelas atau memeriksa makna yang sesungguhnya, sehingga dapat memberikan konsep kepekaan yang implisit. Schutz meletakkan hakikat manusia dalam pengalaman subyektif, terutama ketika mengambil tindakan dan mengambil sikap terhadap dunia kehidupan sehari-hari. Dalam pandangan Schutz, manusia adalah makhluk sosial, sehingga kesadaran akan dunia kehidupan sehari-hari adalah sebuah kesadaran sosial. Dunia individu merupakan dunia intersubyektif dengan makna beragam, dan perasaan sebagai bagian dari kelompok. Manusia dituntut untuk saling memahami satu sama lain dan bertindak dalam kenyataan yang sama. Dengan demikian ada penerimaan timbal balik, pemahaman atas dasar pengalaman bersama, dan tipikasi atas dunia bersama. Melalui tipikasi inilah manusia belajar menyesuaikan diri ke dalam dunia yang lebih luas, dengan juga melihat kita sendiri sebagai orang yang memainkan peran dalam situasi tipikal.

Fenomenologi, pada dasarnya mempelajari struktur tipe-tipe kesadaran yang terentang dari persepsi, gagasan, memori, imajinasi, emosi, hasrat, kemauan sampai tindakan, baik itu tindakan sosial maupun dalam bentuk bahasa. Struktur bentuk-bentuk kesadaran inilah yang dinamakan kesengajaan yang terhubung dengan sesuatu. Kesengajaan sendiri dibentuk oleh noema (dasar pikiran) dan noesis (sisi ideal di dalam pikiran, bukan obyek yang sebenarnya). Noema dan noesis dihubungkan dengan intuisi, sedangkan ego dan super ego menggerakkan intuisi. Struktur kesadaran dalam pengalaman ini yang pada akhirnya membuat makna dan menentukan isi dari pengalaman (content of experience) (Husserl dalam Engkus Kuswarno:2009:22).

Penelitian ini menggunakan metode fenomenologi sosial Alfred Schutz, untuk 
memahami suatu gejala dalam konteks kehidupan melalui situasi tertentu. Schutz (Ritzer, 2003: 94) memusatkan perhatian pada cara orang memahami kesadaran orang lain sementara mereka hidup dalam aliran kesadaran mereka sendiri. Schutz juga menggunakan perspektif intersubjektivitas dalam pengertian lebih luas untuk memahami kehidupan social, terutama mengenai ciri sosial pengetahuan. Fenomenologi yang mempelajari struktur pengalaman dan kesadaran manusia mencoba mencari pemahaman bagaimana manusia mengkonstruksi makna dan konsep-konsep penting dalam kerangka intersubyektivitas. Intersubyektivitas dibentuk oleh hubungan antar manusia (Kuswarno:2009:2). Dalam pendekatan fenomenologi Alfred Schutz, subyektivitas dipandang sebagai titik kunci untuk membuat obyek menjadi bermakna (Agus Salim: 2006:169). Pada pendekatan Schutz, subyektivitas dipandang sebagai titik kunci untuk membuat obyek menjadi bermakna. Menurut Schutz, masyarakat membentuk dunianya sendiri melalui kesadaran konstitutif maupun kesadaran rekonstitutif, yang melakukan tindakan apa adanya. Schutz menyarankan hendaknya penelitian sosial lebih fokus pada dunia kehidupan sehari-hari. Realitas berada dalam kegiatan intersubyektif sehingga ciptaan dari pikiran selalu berada dalam proses interaksi para aktor yang terlibat di dalam kehidupan sehari-hari (Agus Salim:2006:172). Aktor adalah sebutan Schutz untuk individuindividu yang melakukan pemaknaan atas suatu fenomena.

\section{Metode Penelitian}

Objek penelitian ini adalah individu yang merupakan anggota kelompok kelas menengah di provinsi DKI Jakarta dan sekitarnya yang berasal dari generasi Baby Boomers (individu yang lahir tahun 1946-1964), generasi X (individu yang lahir tahun 1965-1982) dan generasi $Y$ (individu yang lahir tahun 1983-2004). Kelas menengah merupakan mereka yang profesional, melek teknologi, menjunjung nilai-nilai spiritual, memegang norma keluarga, mengakses informasi dan internet \& melek gaya hidup. Metode atau teknik penentuan informan yang dipergunakan adalah metode purposive sampling.

Responden penelitian ini berjumlah 14 orang. Tiga orang berasal dari keluarga generasi babyboomers, enam orang dari generasi $\mathrm{x}$ dan lima orang berasal dari generasi y. Keseluruhannya berasal dari kelompok kalangan menengah di Jabodetabek dengan tingkat pendidikan D3 sampai S1. Tingkat pendapatan responden berkisar antara Rp 4 juta sampai dengan Rp 15 juta. Lama pernikahan responden yang diambil sekitar 6 bulan -6 tahun untuk generasi y, 7-25 tahun untuk generasi $\mathrm{x}$ dan sampai generasi babyboomers.

Semua responden berasal dari kalangan yang peduli terhadap kesehatan dan melek perbankan Generasi Babyboomers diantaranya: Boyke Soekapdjo jurnalis, Teguh Wahyudi (51) PNS, Teguh Handoko (51) jurnalis. Generasi X: Diana Astuti (47) PNS, Irwan Setyawan (46) jurnalis, Suleman Nur Alam (44) peneliti, Rosita (45) wiraswasta, Dewanti Lestari 
(44) jurnalis, Mathius Lay (39) peneliti. Dan Generasi Y, Rosslain Wiharyati (30) PR, Bayu (30) peneliti, Miftahul Jamal (29) Event Organizer, Adit Octo (29) karyawan swasta, Sella Panduarsa Gareta (28) jurnalis.

Paradigma yang digunakan dalam penelitian ini adalah paradigma konstruktivis. Penelitian ini memiliki tujuan utama untuk memaknai (atau menafsirkan) makna-makna yang dimiliki orang lain tentang dunia. Sejumlah asumsi konstruktivisme menurut Crotty (Moleng: 2010) adalah makna-makna dikonstruksi oleh manusia agar mereka bisa terlibat dengan dunia yang tengah mereka tafsirkan. Proses penelitian kualitatif bersifat induktif di mana di dalamnya peneliti menciptakan makna dari data-data lapangan yang dikumpulkan. Dalam penelitian ini, penulis berusaha memahami fenomena yang terjadi dalam perubahan makna pernikahan antar generasi Baby Boomers, Generasi X dan Generasi Y di kalangan kelas menengah masyarakat di wilayah provinsi DKI Jakarta dan sekitarnya

Dalam melakukan kajian ini, peneliti berupaya mengumpulkan dan menelaah sebanyak mungkin informasi, baik dari kegiatan focused-group discussion (FGD), diskusi kelompok kecil, wawancara lebih mendalam dengan 12 narasumber, observasi non partisipan dan kajian dokumen serta melakukan derajat konstruksi dan pentipean (tipikasi) terhadap tema-tema yang muncul dari hasil wawancara, agar peneliti mendapatkan gambaran, pemahaman secara menyeluruh dan komprehensif terhadap pelbagai faktor serta elemen-elemen yang ada dan yang mempengaruhi hasil penelitian. Tipikasi dilakukan secara bertahap melalui konstruk pertama dan konstruk kedua. Pada konstruk pertama, data yang diperoleh catatan mengenai pengetahuan, pemahaman, kesadaran, motif dan pihak yang paling mempengaruhi informan terhadap substansi yang akan diteliti. Konstruk kedua memperlihatkan lebih terperinci lagi tipikasi terhadap materi substansi penelitian hingga diperoleh model berdasarkan data-data yang diperoleh dari informan.

\section{Hasil Penelitian dan Pembahasan}

Penelitian ini menjadikan komunikasi kelompok sebagai sebuah cara untuk mengetahui proses perubahan makna pernikahan antar generasi di kalangan kelas menengah di wilayah DKI Jakarta dan sekitarnya. Pada saat mereka berinteraksi, peneliti mempelajari pengetahuan, pengalaman dan kesadaran informan sesuai konsep Fenomenologi Alfred Schutz, yang mencari pemahaman bagaimana manusia mengkonstruksi makna dan konsep-konsep penting dalam kerangka intersubyektivitas. Menurut Schutz, masyarakat membentuk dunianya sendiri melalui kesadaran konstitutif maupun kesadaran rekonstitutif, yang melakukan tindakan apa adanya. Bagi Jamal (salah satu responden keturunan Arab) menikah bukan hanya persoalan dirinya suka kepada calon isteri atau calon isteri suka kepadanya, tapi lebih kepada menyambung keturunan. Menurut Jamal, adat Arab masih sama dari dulu hingga sekarang. Bagi Jamal, makna pernikahan 
adalah menjaga keturunan agar penerus keluarga besar Arab-nya selalu ada. Konsep seperti itu diajarkan oleh leluhur keluarga besarnya dan diajarkan terus turun- temurun dari generasi ke generasi.

Jamal mengaku sebagai generasi ke68 dari marga Al Mutahar, salah satu trah keluarga Arab yang berhulu pada keluarga Sayyidina Ali bin Abi Tholib, menantu Rasululloh Muhammad SAW. Jamal menyatakan dirinya merupakan orang Arab yang modern, yang tidak terlalu memikirkan urusan orang lain. Jadi kalau ada pihak-pihak yang melakukan hubungan sesama jenis apakah itu antar laki-laki atau antar perempuan atau tukar menukar pasangan (swinger), sepanjang mereka hanya menyatakan di antara mereka saja dan tidak menyatakannya di depan publik atau masyarakat luas, diserahkan kembali kepada mereka.

Sementara itu, mengenai ketentuan hukum perkawinan di Indonesia, narasumber lain yang bernama Oci mengatakan hukum negara untuk mempermudah administrasi saja. Terutama untuk masalah materi dan surat-surat anak. Kalau hukum adat dan agama lebih buat menenangkan orang tua atau keluarga, namun yang menyebalkan menurut Oci, di Indonesia pernikahan secara hukum negara tidak dapat dilaksanakan karena pernikahan yang dicatat adalah pernikahan atas dasar salah satu agama yang diakui negara, jadi mau tidak mau pernikahan secara agama hukumnya wajib di Indonesia.

Sedangkan makna pernikahan menurut Oci adalah legalisasi komitmen. Yang penting bukan pernikahannya tapi komitmen kenapa dua orang memutuskan untuk menikah. Kalau komitmen Oci dan suaminya adalah untuk hidup bersama dalam suka dan duka. Setelah punya anak, komitmennya adalah membesarkan anak. Membuat anak mandiri dan bisa menjadi manusia yang berguna bagi sesama. Oci mengatakan untuk makna pernikahannya yang paling banyak mempengaruhi adalah contoh dari orang tua. Sedangkan untuk pendapat Oci mengenai fenomena lesbian, gay dan swinger menurut Oci, itu hanya perbedaan preferensi saja. Menanggapi perilaku swinger, Oci menyampaikan bahwa perilaku itu mencuat ke permukaan akibat terlalu banyak norma yang mengikat seseorang. Pernikahan terlalu diidealisasi sehingga akhirnya malah banyak yang tertekan, bosan, dan malah membuat hal yang aneh-aneh. Pada intinya, Oci mendukung persamaan hak kaum lesbian dan gay tapi menolak swinger.

Sementara itu Sella (salah satu narasumber yang berasal dari suku Jawa) memandang hukum pernikahan di Indonesia sudah bagus. Artinya, sudah jelas melindungi hak-hak perempuan, serta keturunan, karena mempertimbangkan falsafah negara yaitu Pancasila. Sella menyampaikan alasan pernikahannya adalah karena cinta walaupun setelah menikah baru menyadari kalau pedoman pernikahannya yang pertama adalah agama dan kedua adalah konsep pernikahan kedua orang tuanya. Cara berkeluarga kedua orang tuanya melekat dalam pikiran Sella. Ayah dan Ibu Sella tidak pernah ribut. Ayahnya yang tentara adalah seorang 
yang humoris kendati tetap tegas pada saat yang diperlukan, sedangkan Ibunya adalah seorang guru, yang disiplin tapi terbuka kepada anak-anaknya. Sella dan adiknya merasa nyaman dengan pola perkawinan kedua orang tuanya. Bagi Sella makna pernikahan adalah membangun keluarga, memelihara atau menjaga keturunan dan menjalankan ibadah.

Menurut Sella hubungan sejenis itu lebih complicated. Sementara kalau kumpul kebo menurut Sella itu murni mengadopsi budaya Barat karena kalau di budaya Timur, khususnya Indonesia ada budaya kumpul kebo, maka kumpul kebo akan ada di dalam budaya Indonesia. Sella menambahkan orang yang memilih kumpul kebo adalah pasangan yang tidak mempercayai institusi pernikahan. Menurut Sella fenomena lesbian, gay, kumpul kebo, swinger, aborsi, tidak akan mengganggu makna pernikahan Sella dan suami bila dikaitkan dengan konsep pernikahan berbasis hukum agama, negara dan norma masyarakat/adat.

Hal serupa juga dikemukakan oleh Adit tentang pernikahan. Pernikahan menurut Adit Octo (narasumber yang berprofesi sebagai Master of Ceremony) adalah suatu janji suci atau sakral yang harus dijalankan oleh ke-2 pasangan untuk sekali seumur hidup. Adit mengakui peran orang tuanya dalam pembentukan makna pernikahannya sangat besar. Menyikapi fenomena gay dan lesbian, Adit menyatakan hal itu sebagai suatu penyimpangan yang dilakukan oleh beberapa orang, mungkin dari beberapa orang tersebut dipengaruhi oleh faktor lingkungan, keluarga, dan sebagainya. Menurut Adit hukum pernikahan di Indonesia adalah suatu norma dan budaya yang wajib dijalankan oleh semua warga negara Indonesia, apabila tidak ingin difitnah melakukan perbuatan berzina.

Sementara itu, Menyoal pergeseran makna pernikahan, Rosita (narasumber yang terpaut usia 14 tahun dengan suaminya) mengatakan bahwa perkawinan itu hal yang sakral dan tidak bisa dibuat main-main. Tapi mungkin saja setelah pernikahan itu terjadi biasanya ada pergeseran kesakralan itu sendiri, biasanya hal ini akan dipengaruhi oleh penghasilan yang meningkat, jabatan yang semakin tinggi, life style, komunitas dan yang paling penting adalah setelah diamat-amati rumput di kebun kita tidak hijau lagi sementara rumput-rumput di luar sana sangat hijau.

Terkait dengan makna pernikahan, prinsip Dewanti (narasumber yang sudah mandiri sejak sebelum menikah), dalam menikah adalah membutuhkan teman hidup, selain karena aturan agama. Bagi Dewanti, prinsipnya yang penting laki-laki yang mencintai perempuan. Makna lain dari pernikahan menurut Dewanti adalah masing-masing pihak saling menghormati, saling mempertahankan pernikahan, memiliki komitmen tinggi satu sama lain dan untuk melanjutkan keturunan. Dewanti mempelajari makna pernikahan tersebut dari pernikahan Bapak-Ibunya.

Salah satu peserta FGD lainnya, Teguh Handoko (narasumber yang menikah dengan pasangan yang berbeda agama) menyatakan menikah adalah karena perintah agama dan manusia memiliki nafsu. Teguh merasa jodohnya belum 
ketemu sampai usianya 31 tahun, Teguh bertemu dengan seorang perempuan yang berbeda usia tujuh tahun. Mungkin karena jodoh jadi dimudahkan. Teguh juga menyatakan selain bertukar pikiran dengan teman-teman, juga pernah mengikuti kelompok-kelompok pengajian seperti Jemaat Tabligh. Menanggapi fenomena swinger, Teguh menyatakan perbuatan itu tidak benar tapi menjadi privasi masingmasing. Dalam wawancara secara terpisah, Teguh menyatakan makna pernikahan akan bergeser dan bisa bergeser dari yang sakral menjadi formalitas. Banyak hal yang mempengaruhinya seperti kemajuan teknologi yang menghadirkan begitu beragam informasi yang dapat diakses seketika dari beragam belahan dunia, lingkungan sekitar yang longgar terhadap pemahaman ajaran agama dan berubahnya pemaknaan pernikahan yang dimiliki generasi yang lebih muda.

Mengenai fenomena swinger, Teguh menyatakan hal itu bukan kelainan tapi lebih kepada keinginan untuk bereksplorasi, hanya bertualang dan ingin berfantasi dan "having fun". Teguh menyatakan kemungkinan penyebab orang berperilaku swinger adalah norma-norma agama sudah tidak dianggap lagi. Dalam dunia modern norma-norma agama sudah tidak dianggap lagi. Teguh menceritakan perkataan temannya yang menyatakan, sebenarnya keinginan untuk berfantasi pasti ada pada tiap laki-laki, tapi hal itu amat tergantung dengan keberanian dan kemampuan finansialnya. Tapi biasanya kalau agama dan moralnya kuat, akan tetap dengan isteri sendiri.
Sementara peserta lain FGD, Irwan Setyawan (narasumber yang berprofesi sebagai jurnalis) menyatakan menikah pada usia 28 tahun, dua tahun lebih tua dari isterinya. Pada tahun 2015, pernikahannya menginjak usia 18 tahun. Menurut Irwan, makna pernikahan yang dilakoninya saat ini adalah yang pertama, sebagai ibadah, kedua, melanjutkan keturunan dan ketiga menambah kebahagiaan seseorang. Bagi sebagian besar orang, khususnya di tanah air, perkawinan masih dianggap sesuatu yang suci dan sakral. Menyoal fenomena gay, lesbian, swinger dan kumpul kebo, Irwan mengira lebih disebabkan terjadi karena lingkungan. Di lingkungan yang mendukung seks bebas, lesbi, atau sejenisnya, maka lama kelamaan orang yang berada di lingkaran tersebut akan merasa apa yang mereka lakukan adalah biasa. Dianggap tidak menjadi masalah. Tentu saja, bisa terjadi perubahan pandangan bagi seseorang terhadap makna pernikahan itu sendiri jika di lingkungannya menganut pemahaman makna yang berbeda.

Hal senada juga dikemukakan oleh Diana Astuti (narasumber yang sudah berpacaran dengan calon suami sejak di semester VIII bangku perkuliahan). Menurut Diana fenomena lesbian dan gay merupakan penyimpangan. walaupun (aktivitis gender) telah mengatakan atau menemukan itu bukan penyimpangan. Fenomena tersebut bukan mempengaruhi makna, namun orang-orang tersebut menambahkan makna pernikahan dengan memaksakan untuk pengakuan secara legal. Mengenai makna pernikahan, Diana mengatakan makna pernikahan secara 
agama memiliki arti yang tetap, karena peraturan agama berdasarkan ajaran Tuhan. Namun aturan manusia bisa saja berubah, berdasarkan "seolah-olah" mengakomodir kepentingan yang terlibat golongan tersebut. Diana menyatakan yang menggeserkan makna pernikahan adalah orang-orang yang mengalami "penyimpangan" tersebut dengan dalih untuk melegalkan bahwa tindakannya sebagai sesuatu yang normal.

Diskusi dengan kelompok kecil juga dilakukan oleh peneliti untuk melengkapi data penelitian. Diskusi dengan Suleman Nur Alam, Mathius Lay dan Bayu yang dilakukan pada 26 Mei 2015 di Kalibata City, Jakarta Selatan mendapati Suleman Nur Alam memaknai pernikahannya sebagai sesuatu yang sakral bahkan sangat sakral karena didalamnya dilakukan ijab dan kabul yang menyiratkan segala sesuatu yang dulunya haram telah berubah menjadi halal. Menikah bagi Suleman adalah penyatuan dua manusia, laki-laki dan perempuan yang hanya dapat disatukan oleh Tuhan lewat perantara imam. Di dalam pernikahan juga tumbuh cinta dan kasih sayang. Sementara alasan Mathius Lay yang asli Flores, Nusa Tenggara Timur (NTT), untuk menikah adalah agar dia dapat melegalkan persetubuhan, melestarikan garis keturunan keluarga, nama marga tetap eksis dan menjaga keberlanjutan keturunan.

Dalam pendekatan fenomenologi Alfred Schutz, subyektivitas dipandang sebagai titik kunci untuk membuat obyek menjadi bermakna (Agus Salim: 2006:169). Menurut Schutz, masyarakat membentuk dunianya sendiri melalui kesadaran konstitutif maupun kesadaran rekonstitutif, yang melakukan tindakan apa adanya. Realitas berada dalam kegiatan intersubyektif sehingga ciptaan dari pikiran selalu berada dalam proses interaksi para aktor yang terlibat di dalam kehidupan sehari-hari (Agus Salim:2006:172). Menurut Schutz, manusia mengkonstruksi makna di luar arus utama pengalaman melalui proses "tipikasi". Hubungan antar makna pun diorganisasikan melalui proses tipikasi tersebut atau biasa juga dinyatakan sebagai stock of knowledge yang menjelaskan bahwa kumpulan pengetahuan memiliki kegunaan praktis dari dunia itu sendiri, bukan sekedar pengetahuan tentang dunia.

Tipikasi dalam penelitian dimulai dengan melakukan konstruk pertama dari hasil diskusi kelompok dan wawancara mendalam terhadap informan yang belum dipilahpilah sesuai dengan substansi yang banyak muncul. Hasil ini meliputi cerita informan sebelum menikah, ketika tiga bulan menjalani pernikahan berlangsung dan sesudah tiga bulan pernikahan. Dari sini kemudian dicari motif mereka menikah, tindakan apa yang dilakukan berdasarkan contoh pihak yang paling mempengaruhi mereka dalam memutuskan untuk menikah. Kemudian konstruk pertama juga meneliti pengetahuan informan mengenai legalisasi pernikahan di Indonesia, baik secara hukum negara, hukum agama maupun norma/aturan adat dan masyarakat. Tipikasi konstruk pertama juga menggali konsep masa lalu dan masa depan para informan. Dua fase itu oleh Schutz diberi nama tindakan in-order-to motive (Umzu-Motive), yang merujuk pada masa akan datang; dan tindakan because-motive (Weilmotiv) yang merujuk pada masa lalu. (Engkus 
Kuswarno: 2009:111).

Tipikasi pada proses konstruk kedua lalu dilakukan untuk memperoleh sejumlah pemikiran berdasarkan kesadaran para informan. Simbol-simbol yang diciptakan, dipikirkan dan dipahami oleh para informan dan diekspresikan melalui percakapan kelompok maupun diskusi dan wawancara merupakan bahasa yang mengikat antara satu infroman dengan informan lainnya. Bahasa itu akan membentuk perilaku komunikasi yang khas di kalangan informan dari tiga generasi yang bertemu dalam satu percakapan. Memberi kesempatan atau membiarkan para informan berbicara atau berperilaku apa adanya sebagaimana yang mereka kehendaki akan memunculkan perilaku yang tersembunyi yang justru menjadi kajian dari penelitian ini.

Hasil konstruk kedua yang diserap dari fakta konstruk satu, memperoleh gambaran mengenai empat hal pokok hasil eksplorasi seluruh informan yakni pandangan informan terhadap hukum pernikahan di Indonesia, makna pernikahan masing-masing informan dari generasi yang berbeda ketika berinteraksi dengan pasangannya masingmasing, pihak yang paling berpengaruh dalam pernikahan masing-masing informan dan pandangan tentang fenomena lesbian, gay, kumpul kebo, swinger, seksual bebas, aborsi, yang secara eksplisit memperlihatkan fenomena tersebut tidak sesuai dengan aturan hukum pernikahan di Indonesia. Konstruk kedua menghasilkan model-model yang dikembangkan informan dari tiga generasi terhadap empat hal pokok dari pemaknaan terhadap pernikahan mereka.
Generasi Baby Boomers menyatakan pernikahan merupakan cara Tuhan agar manusia dapat melestarikan ras nya sendiri. Pernikahan merupakan penyelamatan ras homo sapiens/manusia untuk tetap lestari (human survival), karena tanpa proses intim yang dilegalisasi melalui pranata pernikahan, manusia akan punah. Jadi, pernikahan merupakan lembaga pelestarian umat manusia. Pernikahan adalah kodrat yang harus dilalui agar ras manusia tetap lestari. Kodrat adalah anugerah (given), sesuatu yang sudah disiapkan dari sananya. Selain itu pernikahan juga merupakan perintah agama dan fitrah manusia untuk hidup berpasangpasangan antara laki-laki dan perempuan agar manusia saling mengisi kebutuhan fitrahnya karena manusia memiliki nafsu. Rerata generasi Baby Boomers memaknai pernikahan sebagai kodrat, penyatuan antara laki-laki dan perempuan sebagai satu cara untuk melestarikan umat manusia, menghalalkan hubungan seksual dan menjalankan perintah agama.

Sedangkan dari kelompok generasi $\mathrm{X}$, menyatakan makna pernikahan adalah ikatan suci antara laki-laki dan perempuan di hadapan Allah SWT, untuk memiliki keturunan, ibadah dan menambah kebahagiaan. Selain itu makna pernikahan adalah untuk melestarikan marga karena keluarga masih kuat memegang adat, sakral dan merupakan peristiwa penting dan bersejarah dalam kehidupan kendati pada segelintir orang, pernikahan lebih fokus pada materi dan kesenangan sesaat. Disamping itu terdapat juga pendapat lain, bahwa pernikahan adalah untuk memiliki 
teman hidup dan melegalkan persetubuhan. Rerata makna pernikahan dari kelompok generasi $\mathrm{X}$ adalah sebagai ibadah (menghalalkan yang haram menjadi halal), sakral, untuk memiliki keturunan, menjaga nama marga dan mencari teman hidup. Makna pernikahan dari generasi Y adalah pernikahan merupakan legalisasi komitmen, mengejawantahkan cinta dan untuk melestarikan keturunan, dengan prinsip melihat bibit, bobot dan bebet walaupun tidak kaku. Pernikahan merupakan janji suci atau sakral yang dilaksanakan sekali seumur hidup. Rerata makna pernikahan dari generasi $\mathrm{Y}$ adalah saling mencintai, memiliki komitmen, menjaga keturunan dan memelihara nama besar keluarga. Model yang dihasilkan dari makna pernikahan ini adalah mencuatnya unsur biologis dan non biologis dengan masing-masing mencakup, biologis yakni melegalkan persetubuhan, memelihara keturunan, kodrat manusia dan melestarikan marga keluarga besar. Sedangkan yang non biologis adalah peles- tarian ras manusia, peristiwa sakral dan kudus, legitimasi komitmen, perwujudan kebahagiaan, melanggengkan percintaan dan menjalankan perintah agama. Penggambaran model dalam gambar, dapat dilihat pada gambar 1 .

Untuk isu lesbian, gay, swinger, seksual bebas, kumpul kebo didapati bahwa seluruh informan menolak atau tidak setuju dengan perilaku swinger atau tukar menukar pasangan berhubungan intim, karena bertentangan dengan norma hukum negara, agama dan masyarakat serta dapat ditindak dengan tegas oleh aparat penegak hukum di Indonesia. Sedangkan sekitar separuh informan tidak terlalu peduli pada fenomena gay, lesbian, swinger atau kumpul kebo, selama tidak terjadi, berkaitan dan atau merugikan kehidupan mereka. Secara lebih terperinci dari generasi Baby Boomers didapati pendapat yang mengatakan tokoh agama gagal dalam mengkomunikasikan arti pernikahan. Bila manusia memaksakan sesuatu di luar kodratnya, tanpa disadari

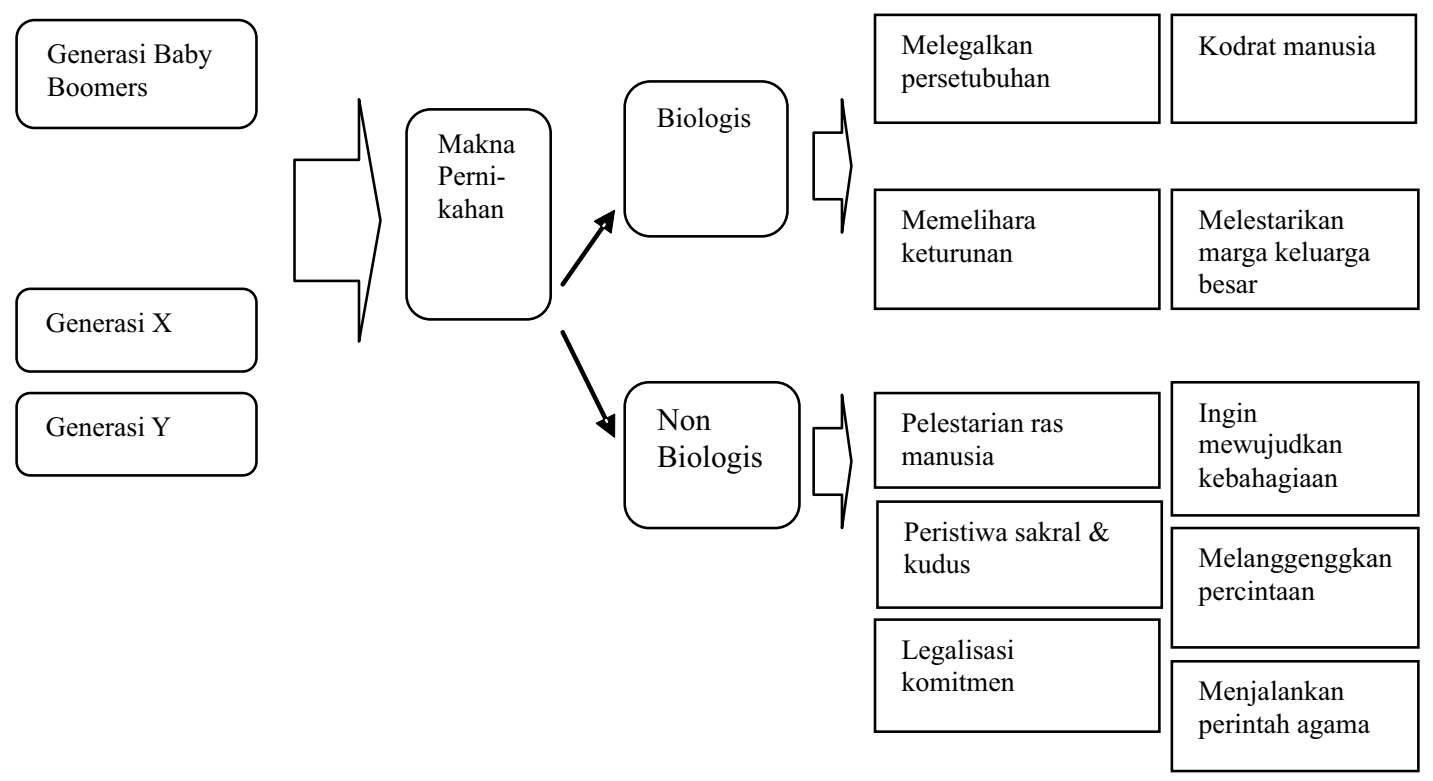

Gambar 1. Model Komunikasi kelompok tentang makna pernikahan berdasarkan unsur biologis dan non biologis 
akan bergerak pada kepunahan manusia itu sendiri mengingat inti pernikahan adalah human survival, pelestarian ras secara alami dan tidak terjebak pada asesoris berupa ritual Ijab Kabul maupun Sakramen pernikahan di gereja. Mengingat sifatnya hanya aksesoris, penganut lesbian dan gay pada akhirnya dapat meminta dilakukan sakramen terhadap mereka sebagaimana terjadi di sejumlah negara bagian di Amerika Serikat dan sebagian negara-negara di Eropa. Sementara pendapat informan lainnya dari kelompok Baby Boomers menyatakan sebaliknya bahwa tokoh agama tidak gagal karena memang dinamika hidup adalah seperti itu namun diakui pernikahan bukan lagi lembaga sakral dengan munculnya fenomena legalnya pernikahan sesama jenis, swinger dan kumpul kebo. Pernikahan hanya menjadi instrument bagi kalangan tertentu untuk menunjukkan sebuah perjanjian pertemanan, bukan perjanjian hidup yang diikat dari fitrah hidup manusia. Pendapat lain menyatakan dampak dari legalisasi lesbian, gay dan mencuatnya perilaku swinger, kumpul kebo maupun aborsi menjadikan pernikahan menjadi tidak sakral dan tidak bermakna lagi karena dilakukan hanya untuk mengikuti gaya hidup dan adanya kelainan dalam diri seseorang, pernikahan hanya keinginan untuk bereksplorasi, mencari sensasi atau bertualang sehingga tidak lagi berbasis norma-norma agama. Model yang dihasilkan dari pandangan terhadap fenomena lesbian, gay, swinger, seks bebas adalah polarisasi antara kegagalan dan tidak gagalnya tokoh agama dalam menjalankan syiar agama masing-masing. Bagi kutub gagalnya tokoh agama maka dipandang perlu untuk merevisi UU Perkawinan RI no 1 tahun 1974, sedangkan untuk kutub yang menyatakan tokoh agama tidak gagal dalam menjalankan syiar agamanya UU Perkawinan RI no 1 tahun 1974 tetap berlaku disertai dengan penegakan hukum dibarengi sanksi efek jera dan penguatan tradisi serta pembelajaran tentang pernikahan di dalam suatu keluarga. Model pandangan tiga generasi terhadap fenomena gay, lesbian, swinger, kumoul kebo dan seksual bebas dapat dilihat pada gambar 2 .

Keluarga, terutama yang memiliki hubungan vertikal yaitu kakek-nenek, ayah-ibu, sangat memiliki pengaruh dalam pembentukan makna perkawinan bagi keturunannya. Hampir semua informan menyatakan dengan tegas bahwa pihak orang tua adalah pihak yang memiliki kekuatan besar dalam memberi teladan untuk membentuk model institusi keluarga. Selain orang tua, informan dalam penelitian juga menyebutkan peran lingkungan terdekat seperti keluarga besar maupun teman-teman di tempat bekerja atau suatu komunitas tertentu membuat peta jalan dalam pembentukan makna pernikahan mereka. Model untuk pengaruh terbesar pernikahan mengerucut kepada terbentuknya institusi pernikahan yang dalam banyak sisi mirip dengan generasi sebelumnya dan lebih longgarnya institusi pernikahan atau berbeda sama sekali dengan generasi sebelumnya. Model untuk pemberi pengaruh terbesar dalam perkawinan, dapat dilihat pada gambar 3 . 


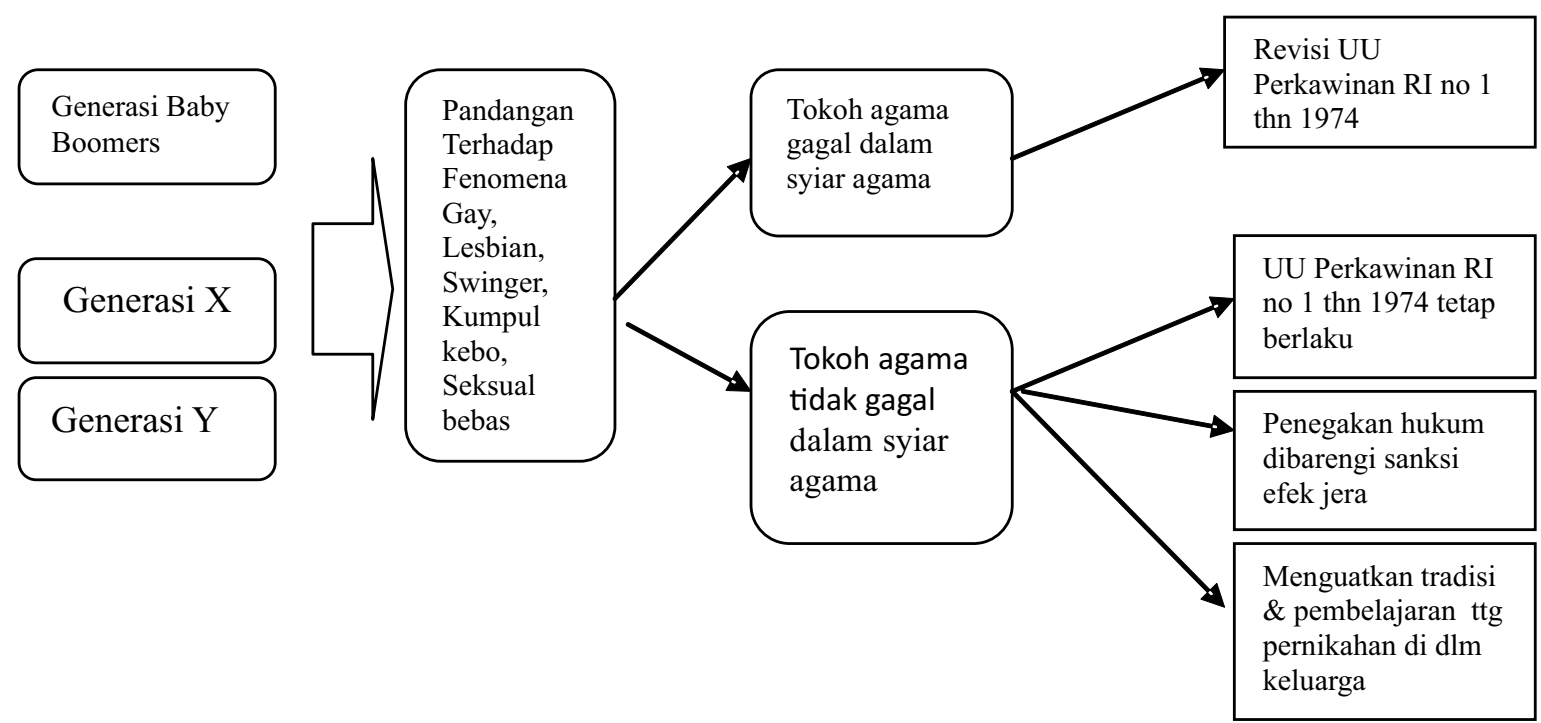

Gambar 2. Model Komunikasi kelompok tentang pandangan terhadap fenomena gay, lesbian, swinger, kumpul kebo dan seks bebas

Dari sisi pandangan informan ter- peristiwa pernikahan lalu dicatatkan pada hadap hukum pernikahan di Indonesia instansi-instansi berwenang agar legal yang berlandaskan UU no 1 tahun 1974 tentang Perkawinan, sebagian besar sepakat bahwa pernikahan harus dilakukan secara agama agar kehidupan rumah tangga memperoleh rahmat dan kasing sayang Tuhan Yang Maha Kuasa. Setelah pernikahan legal dari sisi hukum agama, dari sisi hukum negara. Bila pasangan berasal dari keluarga yang kuat memegang aturan adat istiadat, maka pernikahan juga diwarnai dengan upacara-upacara adat. Namun hukum negara dianggap belum menyelesaikan masalah pada pasangan berbeda agama. Model yang diperoleh dari

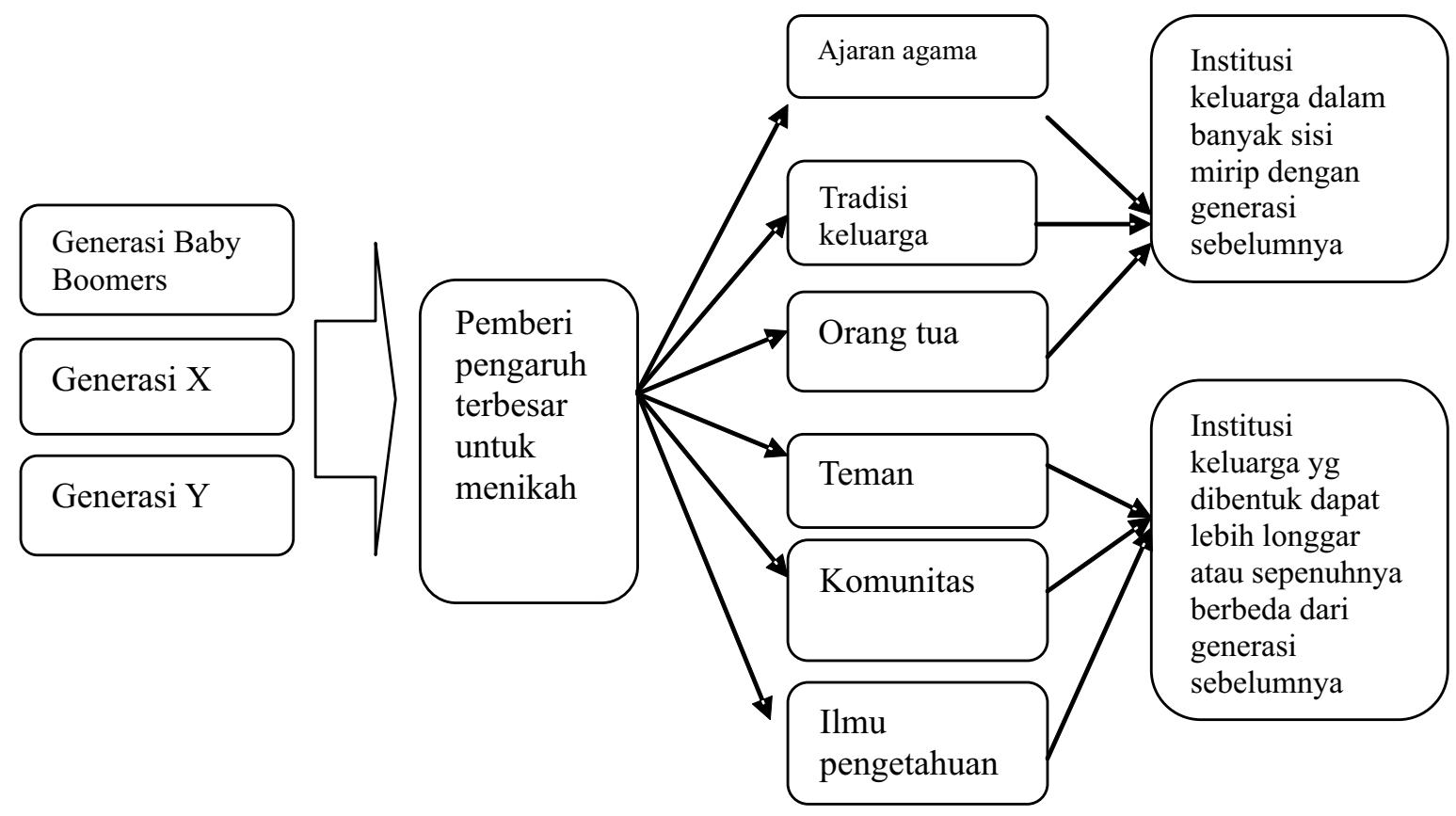

Gambar 3. Model Komunikasi kelompok tentang Pemberi pengaruh terbesar dalam perkawinan 
pandangan mengenai Hukum Perkawinan RI adalah dimulai dengan motif menikah pada suatu generasi, pandangan masingmasing generasi pada hukum yang berlaku sehingga menghasilkan filter institusi pernikahan. Pada aspek pandangan hukum terdapat empat hal yang menjadi fokus yaitu pernikahan sebagai asesoris, perlindungan dan keamanan warisan dalam keluarga, menjaga kesakralan dan kesucian perkawinan serta menahan gempuran pengaruh konsep dan budaya asing terhadap makna perkawinan. Sedangkan filter institusi yang muncul adalah menolak konsep lesbian, gay, swinger dan seksual bebas, perlunya kenyamanan dalam menjalankan perintah agama dan menjaga serta memelihara kerukunan masyarakat.

Pandangan para informan tiga generasi terhadap konsep hukum pernikahan di Indonesia baik dari sisi agama, negara dan adat istiadat maupun menghasilkan temuan baru yakni adanya pergeseran cara memandang dan penerimaan terhadap perilaku/fenomena gay, lesbian, perilaku seksual bebas yang bertentangan dengan kesakralan hukum baik hukum negara, adat atau norma. Dalam hal ini, generasi Y lebih permisifdengandapatmenerimakeberadaan perilaku tersebut di lingkungannya, bila mereka tidak memproklamirkan atau mengusik rumah tangga generasi Y. Selain itu pandangan terhadap makna pernikahan para informan sangat dipengaruhi oleh cara seseorang dibesarkan lewat hukum agama, aturan adat dan norma masyarakat serta lingkungan tempat dia tumbuh (pengetahuan, pengalaman dan pergaulan).

Pandangan tentang pernikahan pada generasi Baby Boomers masih memiliki keterkaitan dengan generasi $\mathrm{X}$ tapi sudah mulai bergerak melonggar bila dibandingkan dengan generasi Y. Sebagian besar informan generasi $\mathrm{Y}$ memaknai sesuatu yang baru dari sebuah pernikahan yakni memberikan toleransi yang lebih

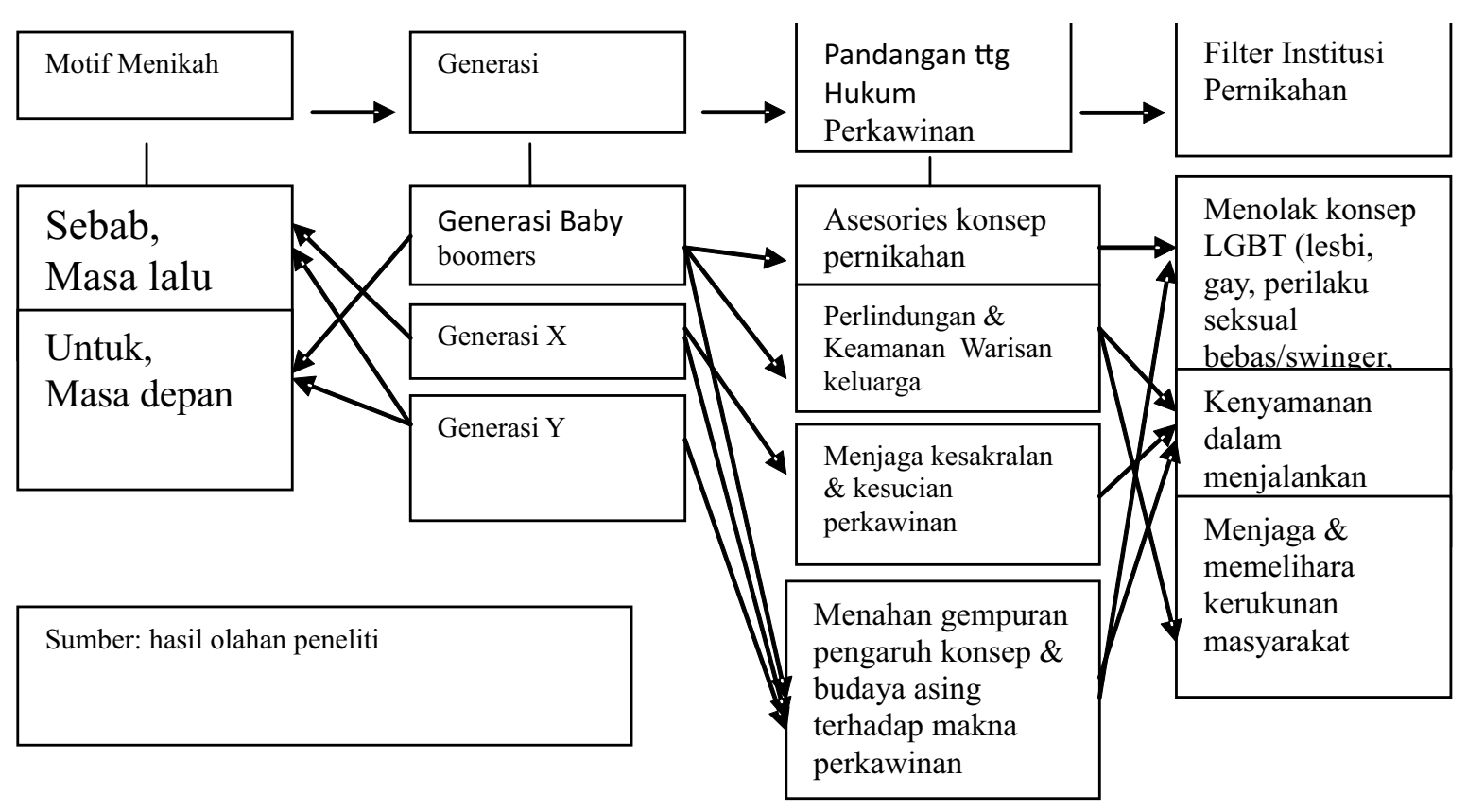

Gambar 4. Model Komunikasi kelompok tentang pandangan mengenai Hukum Perkawinan RI 
besar kepada perilaku yang keluar dari konsep hukum perkawinan di Indonesia. Kondisi ini menciptakan makna pernikahan baru untuk kelompok-kelompok tertentu yang tidak ada kaitannya dengan pengelompokan generasi.

Pada satu sisi ditemukan adanya pergeseran cara memandang dan penerimaan terhadap perilaku/fenomena yang bertentangan dengan kesakralan hukum baik hukum negara, adat atau norma (fenomena lesbian, gay, swinger dan kumpul kebo) yakni pada generasi Baby Boomers dan generasi $\mathrm{X}$, sebagian besar informan menolak perilaku tersebut dengan alasan masing-masing, dan juga kurang dapat menerima keberadaan para pelaku perilaku itu di lingkungan sekitar mereka karena dapat mengganggu makna pernikahan yang diyakini. Namun berbeda pada generasi Y, yang walaupun secara jujur tidak menerima kehadiran mereka namun bila mereka tidak mempertontonkan perilaku tersebut dan hanya untuk kalangan mereka sendiri, hal tersebut tidak dianggap sebagai gangguan bagi pernikahan mereka.

\section{Simpulan}

Generasi Baby Boomers memaknai pernikahannya sebagai penyatuan antara laki-laki dan perempuan sebagai satu cara untuk melestarikan kehidupan umat manusia. Tanpa adanya pernikahan, ras manusia akan punah. Pernikahan merupakan perintah agama dan dipandang sebagai fitrah manusia untuk hidup berpasang-pasangan (laki-laki dan perempuan) agar manusia dapat saling mengisi kebutuhan dan menuntaskan hasrat seksual yang dimilikinya. Sementara generasi $\mathrm{X}$ memaknai pernikahan sebagai ibadah, melegalkan persetubuhan, melanjutkan keturunan, melestarikan marga agar tetap eksis, memiliki teman seumur hidup dan menambah kebahagiaan seseorang. Pernikahan juga dimaknai sebagai sesuatu yang sangat sakral karena merupakan peristiwa penting dan bersejarah dalam kehidupan walaupun ada segelintir orang yang fokus pada materi dan kesenangan sesaat (kawin gantung dan kawin kontrak). Sedangkan generasi Y memaknai pernikahan sebagai legalisasi komitmen kenapa dua orang memutuskan untuk menikah, membangun keluarga, memelihara, menjaga dan melestarikan keturunan. Pernikahan juga dimaknai sebagai janji suci atau sakral yang harus di jalankan oleh kedua pasangan untuk menikah sekali seumur hidup dan menjalankan ibadah berdasarkan cinta.

Pandangan terhadap makna pernikahan sangat dipengaruhi oleh cara seseorang dibesarkan (dalam suatu norma, ajaran agama, aturan adat) dan lingkungan dimana seseorang itu tumbuh (pengetahuan, pengalaman, kesadaran dan pergaulan). Konsep dan hubungan pernikahan yang diperlihatkan oleh orang tua sangat mempengaruhi pembentukan makna pernikahan anak keturunannya. Pada anak-anak yang mendapati hubungan orang tuanya tidak harmonis atau belum memberikan model pernikahan yang baik, pembentukan makna pernikahan akan bergeser keluar dari konsep pernikahan orang tuanya dan si anak akan mencari 
contoh model pernikahan yang baik seperti yang ada di dalam pemikirannya, dari lingkungan terdekat atau lingkungan di mana si anak memiliki intensitas interaksi yang tinggi, misalnya di lingkungan keluarga besar (paman-tante), komunitas atau sahabat karib.

Makna pernikahan antar generasi dapat berubah dengan munculnya pergeseran cara pandang dan model penerimaan terhadap perilaku/fenomena/gejala yang bertentangan dengan kesakralan hukum pernikahan, baik secara aturan negara, adat atau norma seperti fenomena pernikahan sejenis (gay/ lesbian), perilaku tukar menukar pasangan, kumpul kebo dan seks bebas. Generasi Baby Boomers memandang pernikahannya sebagai suatu cara melestarikan ras manusia dan menolak dalil apapun yang melegitimasi fenomena yang bertentangan dengan aturan pernikahan, baik aturan agama, negara maupun adat/norma masyarakat. Generasi $\mathrm{X}$ memandang pernikahannya juga sebagai pelestari ras manusia namun sudah mulai menerima pandangan-pandangan yang mendukung legitimasi kemungkinan munculnya pernikahan sesama jenis kelamin kendati tetap menolak perilaku swinger sedangkan generasi Y lebih permisif dengan keberadaan perilaku lesbian, gay, swinger maupun kumpul kebo yang terdeteksi di lingkungannya. Bagi generasi Y, sepanjang para pelaku penyimpang konsep pernikahan normal yang sesuai dengan UU RI No. 1/1974 tentang Perkawinan, hukum agama dan norma masyarakat, tidak menyampaikannya secara terbuka tentang kecenderungan mereka dan menjadi komunitas terbuka, kelompok generasi Y dapat menerima kehadiran mereka asal tidak mengganggu rumah tangga mereka. Makna pernikahan bukan sekedar bergeser atau berubah dengan mencuatnya fenomena lesbian/gay, swinger, kumpul kebo dan seksual bebas, malah menciptakan makna pernikahan baru untuk kelompok-kelompok tertentu yang tidak ada kaitannya dengan pengelompokan generasi.

Mengingat substansinya yang mendasar, pernikahan perlu diatur oleh agama, negara dan adat istiadat, dalam perjalanan sejarah manusia, banyak fenomena yang muncul dengan esensi yang berseberangan dengan konsep pernikahan sebagai upaya pelestarian ras manusia. Pernikahan yang merupakan penyatuan sepasang manusia, laki-laki dan perempuan, dalam upaya memiliki keturunan secara alami harus berhadapan dengan fenomena pernikahan sejenis, perilaku swinger, kumpul kebo dan lain-lain yang berakibat pada perubahan makna pernikahan yang ada.

Makna pernikahan tiap generasi sangat besar dipengaruhi oleh makna pernikahan generasi sebelumya. Sebaiknya dilakukan penguatan komunikasi antara generasi awal kepada generasi berikutnya akan makna hakiki pernikahan karena terdapat sinyalemen tokoh-tokoh agama dan pihak-pihak yang paling mungkin mengomunikasikan substansi hakiki pernikahan berupa pelestarian ras manusia secara alami, gagal menyosialisasikan ajaran agama tentang pernikahan secara tepat, baik kepada umat maupun kelompok masing-masing. 


\section{Daftar Pustaka}

Blumer Herbert. (1998). Symbolic Interactionism, Perspective and Methode, New Jersey: Prentice-Hall, Inc.

Denzin, Norman K., Yvonna S. Lincoln. (1994). Handbook of Qualitative Research, California: Sage Publication.

Kuswarno, Engkus (2009). Fenomenologi : Metodologi Penelitian Komunikasi, Bandung: Widya Padjadjaran

Littlejohn, Stephen W. (2005). Theories of Human Communication - Eighth Editon, USA: Thomson Wadsworth

Littlejohn, Stephen W \& Foss, Karen (2014). Teori Komunikasi - Penerjemah : Muhammad Yusuf Hamdan, Jakarta:Penerbit Salemba Humanika.

Lubis, L. Indriani, Khasiah (2016). Jurnal Komunikasi ASPIKOM, Vol. 2, No. 6, Januari 2016, Yogyakarta (hal:401-402)
Moeloeng, Lexy J, (2010). Metodologi Penelitian Kualitatif, edisi revisi, Bandung: PT Remaja Rosdakarya.

Ritzer, George, Douglas J Goodman (2003). Sociological Theory - Sixth Edition, New York: Mc Graw Hill

Ritzer, George, et al (2011). Teori Sosiologi Modern - Terj; Alimandan, Jakarta: Prenada Media Group.

Salim, Agus, (2006). Teori \& Paradigma Penelitian Sosial, Buku Sumber Untuk Penelitian Kualitatif. Edisi Kedua, Yogyakarta: Tiara Wacana.

Strauss, William. Neil Howe. (1991). Generations: The History of America's. Future, 1584-2069, New York: William Morrow and Company 